\title{
Digital Literacy in Compensating Children's Learning Difficulties
}

\author{
Nia Hoerniasih ${ }^{1, *}$, Cut Nuraini ${ }^{1}$ \\ ${ }^{I}$ Doctoral student, Postgraduate Program, Universitas Pendidikan Indonesia, Bandung, Indonesia \\ "Corresponding author.Email: niahoerniasih@yahoo.com
}

\begin{abstract}
Improving digital literacy can help compensate for children's or student learning difficulties. Today's students have become adults in the era of digital media. However, the ability of all social media in IT wealth does not necessarily mean that a child is declared digital literate. That way, children have technological skills to meet the digital demands needed to succeed in school and in life. This article is the result of a study of the extent to which digital literacy acts as a compensation for learning difficulties for children. Besides that, the correlation between digital literacy owned by parents also greatly influences the success rate of family goals in achieving education for their children.
\end{abstract}

Keywords: literacy, digital, family, children

\section{INTRODUCTION}

The acceleration of information technology, especially in the form of digital, gave rise to an increasingly easy and intense situation of interaction between people. This is also supported by an increasingly good internet connection with technology infrastructure, making it easier for individual interactions. The communication space is increasingly open, with only a thin wall between private space and public space. Massive interaction on social media, making the community in a digital container can develop their ideas and creative ideas [1].

However, in the context of ideas, Indonesian people do not yet fully have a literacy basis which is a solid initial foundation. Based on the research report of the Program for International Student Assessment (PISA) reveals, the condition of the literacy tradition of Indonesian society in 2012 was ranked 64 out of 65 countries studied. Meanwhile, the reading index of students in various countries studied, Indonesia's position ranks 57th out of 65 countries.

Digital literacy has meaning as an ability related to hypertextual information, in the sense of reading nonsequential computer-based systems or digital platforms [2]. Thus, the ability to analyze becomes something important. In the words of Gilster[3], digital literacy is interpreted as the ability to read, understand and analyze various digital sources.

In the midst of an era like today, digital literacy is a capability that occupies a strategic position. Because, the position of a news is true or not, it has been determined at the level of intelligence of the digital information lovers community [4]. Information whose truth is very questionable and doubtful, manifests as a free consumption. Then it needs to be anticipated with the ability to sort and read analytically, in order to obtain valid information. The ability to find sources of information that can be accounted for has become very important amid the acceleration of today's digital technology.

Thus, the ability to read Indonesian people, especially children, needs to be directed with intelligence to understand the flow of digital information and the civilization of social media. Intelligence using digital media platforms, the accuracy of spreading ideas, as well as careful access to information is an important skill in the current line of social media transformation.

For this reason, digital literacy needs to be encouraged as a learning mechanism, structured in the curriculum, or at least connected to the teaching-learning system [4]. Aside from learning institutions, digital literacy campaigns also need to hold creative communities and educational organizations based on society that can spread ideas, improve abilities and execute massive movements for intelligent social media.

Digital literacy is also part of UNESCO's long-term plan. In the UNESCO roadmap (2015-2020), digital literacy is an important pillar for the future of education. Digital literacy is a knowledge base, supported by integrated information technology. Furthermore, teacher creativity is very strategic for the development of education in the cyber era.

Massive digital literacy campaigns, by increasing children's reading skills in the midst of the moment are very important as a form of increasing children's intelligence and shaping children's learning outcomes are quite high. Maximum children's learning outcomes and intelligence are influenced by their learning methods that are full of support and adaptation to the digital era. Therefore, the study of digital literacy in improving children's learning outcomes needs to be done.

In the effort to form or succeed a literacy application, determining the strategy is very important. The strategy to build an iteration culture can be done by: 1) conditioning 
the physical environment friendly to the environment; 2) work on the social and affective environment; 3) striving for schools as a literal academic environment. Efforts in the strategy are indicators of success measurement parameters in terms of factors that influence a successful digital literacy

\section{METHOD}

In this study, researchers used a qualitative method in the form of case studies, because it examines events in the form of digital literacy levels in a family. The approach of this research is descriptive can be interpreted as a problem solving procedure that is investigated, by describing or describing the state of research objects at the present time, based on facts that appear or as they are.

Research procedures that use descriptive data in the form of written or oral words from people and observed behavior [5]. The data may be from texts, interviews, field notes, personal documents, notes or memos and other official documents. In addition, in this qualitative descriptive study, researchers use to solve or answer problems that are being faced in the current situation, by taking the steps of collecting, classifying and analyzing data, making conclusions and reports with the main objective to make a picture of a situation objectively in a descriptive situation. In order to find data, research informants must first be determined. Information in this study is data or a person who provides information or information relating to research needs. In this study, the source of informants are several families in the District of Cilamaya Wetan Karawang. While the subject in this study is the level of children's achievement ability or children's learning outcomes.

\section{INSTRUMENTS AND VARIABLES}

In this study, researchers conducted direct observations from house to house in the Cilamaya Wetan area to analyze and record any matters related to family conditions, atmosphere, and facilities available in each house for ease of daily family member activities.

The variable to be measured here is the effect of digital literacy. To find out, the influence or level of digital literacy can be measured in three dimensions, namely the first dimension, technical skills limited to information about the ability to use computers and the internet, the ability to use media actively, and the purpose of using media. The second dimension, criticism understanding is limited to knowing the ability to understand media content, as well as the types of media that are often used, and their influence. The third dimension, communicative abilities is limited to the ability to communicate and build social relations through the media, the ability to participate with the community through the media, and the level of creativity in creating information obtained from the media. The instruments are arranged in the form of questions in a questionnaire or questionnaire as follows:

\begin{tabular}{|c|c|c|c|c|}
\hline No & Component & Indicator of Success & Yes & No \\
\hline 1 & Use (Technicall Skills) & $\begin{array}{l}\text { - Ability to use a computer } \\
\text { - Ability to use a device } \\
\text { - Ability to use media actively } \\
\text { - The intended use of the media }\end{array}$ & & \\
\hline 2 & - Critical Understanding & $\begin{array}{l}\text { - Ability to understand media content and } \\
\text { functions } \\
\text { - Have knowledge of the media } \\
\text { - Intensity towards followers of one media } \\
\text { - The degree of dependence on the media } \\
\text { - Media influences oneself }\end{array}$ & & \\
\hline 3 & - Communicative Abilities & $\begin{array}{l}\text { - Many benefit from social media } \\
\text { - The social media function can add friends } \\
\text { and relations } \\
\text { - The use of media provides benefits } \\
\text { - Media influence attitude formation } \\
\text { - Participate in the media or one of the media } \\
\text { - Has a creative form of a media }\end{array}$ & & \\
\hline
\end{tabular}


Meanwhile, to measure the level of preparedness and influence on the success of children, namely:

\begin{tabular}{|c|c|c|c|c|}
\hline No & Component & Indicator of Success & Yes & No \\
\hline 1 & - Home environment & $\begin{array}{l}\text { - There are litera artifacts (motivational } \\
\text { posters) } \\
\text { - There is a family reading room } \\
\text { - There is a family room } \\
\text { - There is a family dining room } \\
\text { - There is a desk in each room } \\
\text { - There are reading materials in the house } \\
\text { - There are internet learning facilities in the } \\
\text { house }\end{array}$ & & \\
\hline 2 & $\begin{array}{l}\text { - The environment around the } \\
\text { house }\end{array}$ & $\begin{array}{l}\text { - } \text { Posyandu is available } \\
\text { - There is a village or village library } \\
\text { - There is a village PKK center } \\
\text { - home are places to study/study/courses near } \\
\text { - There is a school near home } \\
\text { - There are public facilities near the house } \\
\text { - There is a place of study near the house } \\
\text { home area } \\
\text { - There is an association of children or village } \\
\text { youth }\end{array}$ & & \\
\hline
\end{tabular}

\section{RESULTS}

- From the sample of several families that were the object of study, a conclusion was reached as follows:

- Use (Technicall Skills), Some 90\% of objects (people in Cilamaya) cannot use computers. However, $100 \%$ can use gadgets and gadgets to become the main media as their activities in cyberspace or social media.

- Use (Technicall Skills), Some 90\% of objects (people in Cilamaya) cannot use computers. However, $100 \%$ can use gadgets and gadgets to become the main media as their activities in cyberspace or social media.

- Critical Understanding, a number of $94 \%$ including active users but only $60 \%$ make social media on gadgets as media that have functions to carry out activities such as (buying and selling transactions, online shopping, and communication with groups or groups). In addition, from the results of an analysis of the Cilamaya community, $70 \%$ made the media the center of information and the center of inspiration, where their lifestyles and lifestyles were focused or imitated from social media and media information devices. Like how to dress up, style, how to make food, and so on.
- Communicative Abilities, some $100 \%$ feel the many benefits of media used (gawai) in several types and forms. Lots of content that is enjoyed so as to cause enormous benefits. Among them, 1) can add friends, 2) strengthen communication links, 3) as learning media, 4) as entertainment media to fill the deadlock and to spend free time on the sidelines of work and daily activities, 4) business media for men (Gentlemen) and women (ladies)

- The influence of indicators that influence the success or support of literacy available in the home environment and the environment around the house, as follows:

- $13 \%$ of houses have literacy artifacts (posters and wall posts), and other facilities supporting facilities, such as the internet, multimedia devices, computers, etc.

- The results of the field analysis indicate that a number of regions in Cilamaya have public facilities that support the literacy movement, but the functioning of these facilities varies greatly. There are those that have been actively used and some that have not functioned optimally, even $70 \%$ of the regions have public facilities that are not functioning and are not utilized by the community. Thus, it becomes an indicator of the weighing of 
success and the level of success of the driver

From the results of the field analysis, it can be concluded that the condition of the residence with the condition of the environment around the residence is very influential on the abilities and achievements of children and family members. In addition, the ability to use and use digital media in daily activities and the formation of attitudes, is very influential and determines the success and level of abilities and achievements of children and other family members.

\section{REFERENCES}

[1] R. Kadarsih, "Demokrasi dalam Ruang Publik: Sebuah Pemikiran Ulang untuk Media Massa di Indonesia," J. DAKWAH, vol. IX, no. 1, 2008.

[2] C. Davis and D. Shaw, Introduction to Information Science and Technology. New Jersey: Information Today, 2011.

[3] P. Gilster, Digital Literacy. Canada: John Wiley \& Sons, Inc, 1997.

[4] N. Kurnia and S. I. Astuti, "Peta Gerakan Literasi Digital di Indonesia: Studi tentang Pelaku, Ragam Kegiatan, Kelompok Sasaran dan Mitra," Inf. Kaji. Ilmu Komun., vol. 47, no. 2, 2017.

[5] L. J. Moleong, Metodologi Penelitian Kualitatif, Ketigapulu. Bandung: PT Remaja Rosdakarya, 2013. 